
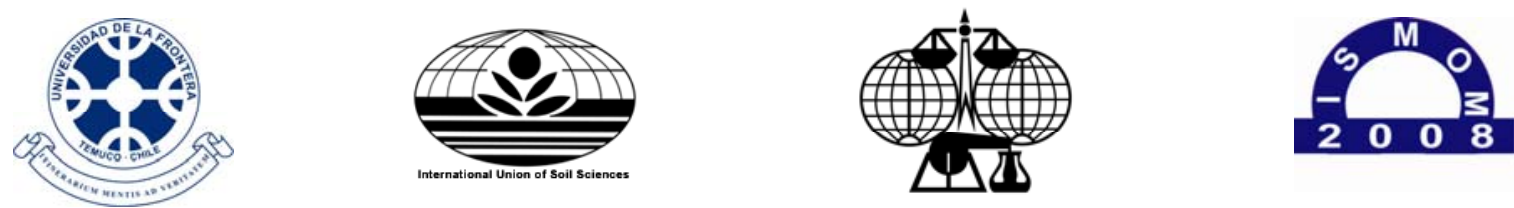

$5^{\text {th }}$ International Symposium ISMOM 2008 - November $24^{\text {th }}-28^{\text {th }}, 2008$ - Pucón, Chile

Keynote papers

\title{
K-7
}

\section{Interaction with Soil Constituents Determines the Environmental Impact of Proteins}

\section{H. Quiquampoix*}

Biogéochimie du Sol et de la Rhizosphère, INRA, 2 Place Pierre Viala, 34060 Montpellier, France

*E-mail: quiquampoix@montpellier.inra.fr

Proteins are important compounds in soils, made up of monomeric amino acids joined by peptide bonds, and there are several reasons for studying their fate in soil: (i) their amino acids are an important source of soil nitrogen, (ii) enzymes secreted by soil microorganisms, plant roots and soil invertebrate guts can be involved in the biogeochemical cycles of soil organic matter (Quiquampoix, 2000; Quiquampoix and Mousain, 2005), (iii) pathogenic proteins such as prions involved in transmissible spongiform encephalopathies (Brown and Gajdusek, 1991; Revault et al., 2005) or insecticidal toxins expressed in transgenic plants (Tapp and Stotzky, 1998; Pagel-Wieder et al; 2004) represent a growing environmental concern.

Proteins generally have a strong affinity for all types of interfaces found in soil, both the solidliquid interfaces of soil minerals and organic colloids and the liquid-gas interfaces developed in a microporous system and dependent on the soil pore-water content. The affinity for various types of interfaces originates in the flexibility of the polypeptide chain and in the diversity of the 20 amino acids that can be classified on an electrical scale as positively, neutrally or negatively charged and on a hydrophobic scale from polar to non-polar. These properties give rise to a large variety of interactions with soil surfaces, relationships that may be dominated by enthalpic or entropic contributions to the free energy. The strong and often largely irreversible adsorption of proteins on the mineral phase of the soil has important consequences not only on their mobility, but also on their resistance to breakdown (proteins as $\mathrm{N}$ source in soil) and functional activity (catalylic for enzymes, infectious for prions, toxic for Bt proteins).

Extracellular enzymes can be secreted into soil solution by microorganisms. This process makes possible the degradation of the soil organic matter since polymers cannot usually pass through the membranes of the microorganisms and need to be hydrolysed into soluble low molecular weight compounds which can reach membrane permeases specific for monomers (sugars, amino acids) or occasionally oligomers. For this reason, they will play an important role in the biogeochemical cycles of $\mathrm{C}, \mathrm{N}, \mathrm{P}$ and $\mathrm{S}$ in soil. A consequence of the adsorption of these extracellular enzymes on mineral surfaces is a shift of the optimal $\mathrm{pH}$ of the catalytic activity toward more alkaline values and a general decrease of their activity.

All proteins can make an important contribution as biochemical substrates in proteolysis reactions in the $\mathrm{N}$ cycle when released in soil after death of biota and lysis of the membranes since they have an average $\mathrm{N}$ content of $16 \%$.

Prion proteins are an infective agent of several transmissible spongiform encephalopathies (TSE). Epidemiological studies of ovine scrapie in Europe and, more recently, the chronic wasting disease of wild cervids (deer, elk and moose) in North America, suggest the possible horizontal transmission from a soil reservoir. 

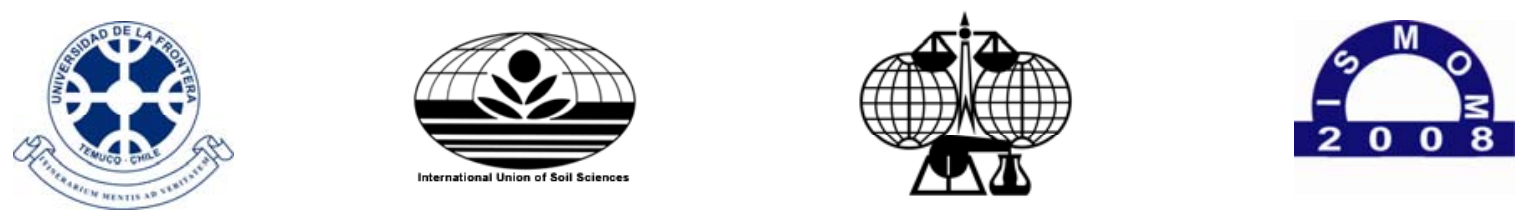

$5^{\text {th }}$ International Symposium ISMOM 2008 - November $24^{\text {th }}-28^{\text {th }}, 2008$ - Pucón, Chile

Keynote papers

Insecticidal toxins, such as the Bt toxin, are associated with the beginning of the first large-scale commercial planting of transgenic crops. The use of transgenic crops expressing the $\mathrm{Bt}$ toxin suggests the possibility that the toxin could be released, survive and then accumulate in the soil when roots are degraded. This, in turn, may trigger the development of resistance towards targeted, pathogenic soil invertebrates and have inhibitory or even lethal effects on non-target, beneficial invertebrates.

All these different proteins released in soil may exhibit a wide range of types of interactions with the mineral surfaces or the organo-mineral complexes. Nevertheless some general tendencies may be identified.

\section{Influence of pH on adsorption of proteins on clay minerals}

Since the pioneering works of Mc Laren et al (1958) it is well established that for most proteins the maximum of adsorption occurs near their isoelectric point (i.e.p.). Early interpretations of this fact included, for $\mathrm{pH}>$ i.e.p. a repulsive electrostatic interaction between the negatively charged protein and the negatively charged clay surface, and for $\mathrm{pH}<$ i.e.p., either a competition of the protons of the solution for adsorption sites (Mc Laren et al., 1958), or a decrease in the amount of protein required to satisfy the negative charge of the clay since the net positive charge of the protein increases as $\mathrm{pH}$ decreases (Armstrong and Chesters, 1964). Alternatively the possibility of an artefact resulting from protein precipitation, more likely to occur at the i.e.p., has been proposed (Durand, 1964).

More recently the fact that the adsorption of proteins on clay mineral surfaces is accompanied by a release of charge compensating cations (McLaren et al., 1958; Albert and Harter, 1973) has been exploited to obtain both the clay surface coverage and the quantity of protein adsorbed, which has led to a different interpretation (Quiquampoix and Ratcliffe, 1992). The latter study is based on the detection by nuclear magnetic resonance (NMR) spectroscopy of the release of a paramagnetic cation, manganese, on adsorption of bovine serum albumin (BSA) on montmorillonite. The fraction of $\mathrm{Mn}^{2+}$ released is assimilated to the fraction of the clay surface covered by the protein. A maximum adsorption occurs near $\mathrm{pH} 4.7$ which is the i.e.p. of BSA, but the quantity of $\mathrm{Mn}^{2+}$ released show a different pattern. Above the i.e.p., both the quantity of protein adsorbed and the quantity of $\mathrm{Mn}^{2+}$ released decrease in the same proportion when $\mathrm{pH}$ increases, indicating a lowering of the surface coverage of the clay surface and confirming the early interpretation of electrostatic repulsions. But below the i.e.p. the quantity of $\mathrm{Mn}^{2+}$ released remains constant when the quantity of protein adsorbed decreases, indicating an unfolding which increases the specific interfacial area of the protein as $\mathrm{pH}$ decreases.

\section{Structural studies of adsorbed proteins}

Studies on the quantity of protein adsorbed on surfaces cannot be separated from the study of the conformation adopted by the proteins on these surfaces. The reason is that a modification towards a more disordered structure contributes to the driving forces of adsorption, since it increases the entropy of the system and thus decreases the Gibbs energy. The modification of conformation also 

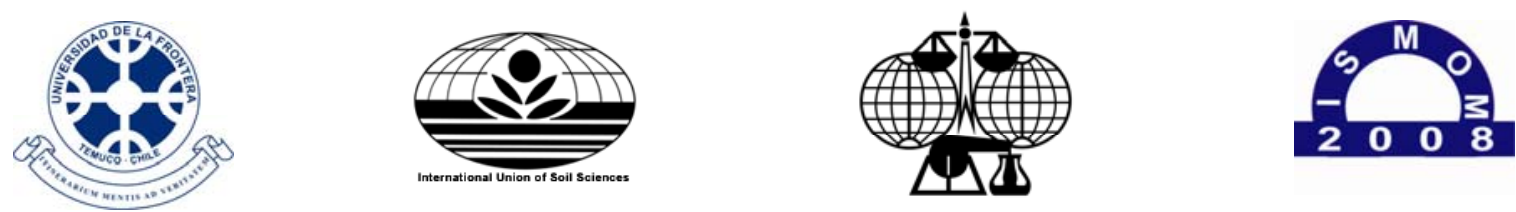

$5^{\text {th }}$ International Symposium ISMOM 2008 - November $24^{\text {th }}-28^{\text {th }}, 2008$ - Pucón, Chile

Keynote papers

can have an effect on the maximum quantity of protein adsorbed, since a modification of conformation may affect the area occupied by each single protein the surface.

The spontaneous adsorption of proteins at constant temperature and pressure leads to a decrease of the Gibbs energy of the system, according to the second law of thermodynamics (Norde and Lyklema, 1991; Haynes and Norde, 1994). The Gibbs energy, G, depends on enthalpy, H, which is a measure of the potential energy (energy that has to be supplied to separate the molecular constituents from one another), and entropy, S, which is related to the disorder of the system.

$$
\Delta_{\text {ads }} \mathrm{G}=\Delta_{\text {ads }} \mathrm{H}-\mathrm{T} \Delta_{\mathrm{ads}} \mathrm{S}<0
$$

with $\mathrm{T}$ being the absolute temperature and $\alpha_{\mathrm{ads}}$ being the change in the thermodynamic functions resulting from adsorption.

Some difficulties arise in the analysis of these processes because enthalpic effects, related to intermolecular forces, and entropic effects, related to the spatial arrangements of molecules, are not totally independent. Intermolecular forces influence the distribution of molecules, and the potential energy also is also dependent on the molecular structure of the system.

The entropic contribution to adsorption can result from a modification of the conformation of the protein. This phenomenon is related to an increase of the rotational freedom of the peptide bonds engaged in secondary structures, such $\alpha$-helices and $\beta$-sheets. The ordered secondary structures are an important part of the densely packed hydrophobic core of proteins. After adsorption, internal hydrophobic amino acids can reach more external positions in contact with the surface, since the amino acids remain shielded from contact with the water molecules of the surrounding solvent phase. If a decrease of internal ordered secondary structures accompanies this process, it will result in an increase of conformational entropy. The gain of conformational entropy, $\mathrm{S}_{\text {conf, }}$, can be calculated from the assumption that four different conformations are possible for peptide units in random structures as compared with only one in $\alpha$-helices and $\beta$-sheets:

$$
\Delta_{\text {ads }} \mathrm{S}_{\text {conf }}=\mathrm{R} \ln 4^{\mathrm{n}}
$$

where $\mathrm{R}$ is the molar gas constant and $\mathrm{n}$ is the number of peptide units involved in the transfer from an ordered secondary structure to a random secondary structure (Norde and Lyklema, 1991; Haynes and Norde, 1994).

No method currently exists which enables the direct measurement of the conformation of proteins in an adsorbed state. Only two methods are suitable for the determination of the tertiary structure of the proteins, and neither can be employed when proteins are adsorbed. One method, Xray diffraction, necessitates the preparation of protein crystals, which is impossible for adsorbed proteins. The other, NMR spectroscopy, is confined to molecules with a sufficiently high tumbling rate to obtain narrow line widths, a condition not compatible with the adsorption on a surface larger in dimensions than the protein itself. In addition the determination of a tertiary structure has a sense only if all the protein molecules have the same structure. In reality it seems probable that the proteins are adsorbed in multiple states (Horbett and Brash, 1987). 

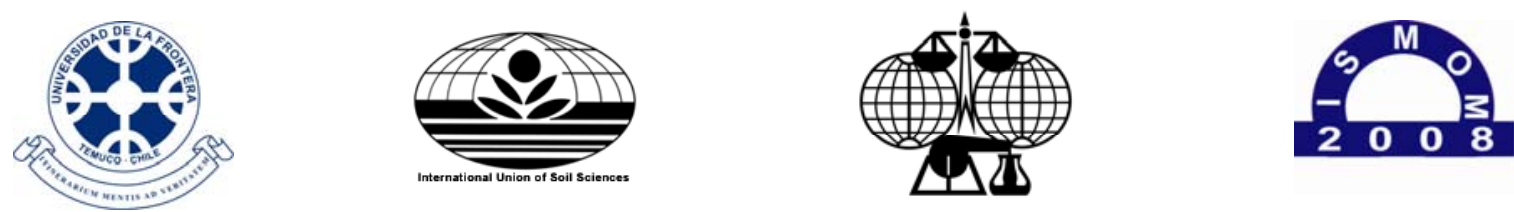

$5^{\text {th }}$ International Symposium ISMOM 2008 - November $24^{\text {th }}-28^{\text {th }}, 2008$ - Pucón, Chile

Keynote papers

For these reasons the secondary structures ( $\alpha$-helices, $\beta$-sheets, random parts) are probably the higher order structures on which information can be obtained. Circular dichroism (Kondo et al, 1991) and infrared spectroscopy (Tarasevich et al., 1975; Quiquampoix et al., 1993; Baron et al., 1999; Servagent-Noinville et al., 2000; Noinville et al., 2004) have been applied to the resolution of these structures for proteins adsorbed on mineral surfaces. Circular dichroism can be used only for the study of adsorption on very small mineral particles due to problems arising from light scattering effects. Kondo et al. (1991) have studied by this technique the modification in $\alpha$-helix content of proteins adsorbed on ultrafine silica particles (diameter of $15 \mathrm{~nm}$ ) and found a greater decrease for the proteins whose adiabatic compressibility is high, i.e. whose flexibility of the structure is high in water. For example BSA retained only 60 to $80 \%$ of its native a-helix content, depending on $\mathrm{pH}$. Infrared spectroscopy does not suffer from light scattering perturbations and has thus been used for the study of the adsorption of BSA on montmorillonite. A decrease in the $\alpha$-helix content and an increase in intermolecular $\beta$-sheet content have been observed for the BSA by FTIR investigations (Servagent-Noinville et al., 2000; Quiquampoix et al., 2002). But the adsorption of $\alpha$-chymotrypsin on montmorillonite has only a very small effect on the secondary structure of this protein (Baron et al., 1999).

\section{Intercalation of proteins between clay sheets}

The suspected protective effect of protein intercalation in clay interlayer position (Loll and Bollag, 1983) has led to a vast number of studies by X-ray diffraction on d (001) spacing of clayprotein complexes (Mc Laren et al., 1958; Armstrong and Chesters, 1964; Albert and Harter, 1973; Harter and Stotzky, 1973). Early interpretations of these results were that the proteins could penetrate between the interlayer spaces by a process of lateral diffusion (McLaren et al., 1958). However such a process is not compatible with the strong, largely irreversible aspect of protein adsorption which implies large activation energy for surface diffusion (Norde, 1986). A more convincing process of intercalation has been proposed (Larsson and Siffert, 1983), where adsorption of proteins occurs on the external surfaces of the clay, but the shear stress induced by the stirring of the suspension may induce an opening of tactoids exposing a new clay surface which is then free to interact with a clay surface already bearing a protein monolayer.

\section{Consequences of electrostatic interactions on enzyme activity}

Two main hypotheses have been proposed to explain the shift of the optimal $\mathrm{pH}$ of the catalytic activity of enzymes adsorbed on negatively charged surfaces such as clay minerals.

The first hypothesis considers that the $\mathrm{pH}$ in the region of the active site of the adsorbed enzyme is lower than the $\mathrm{pH}$ in the bulk of the solution which is effectively measured with a glass electrode and this explains the observed shift (Mc Laren and Estermann, 1957; Durand, 1964; Goldstein et al., 1964; Aliev et al., 1976; Douzou and Petsko, 1984). Indeed the negative charge originating in the isomorphic substitution in the crystalline lattice of the clay is compensated by cations, including protons, which make up a diffuse double layer, and thus the activity of the protons near the surface is higher than in the bulk. But this hypothesis has three serious drawbacks. 

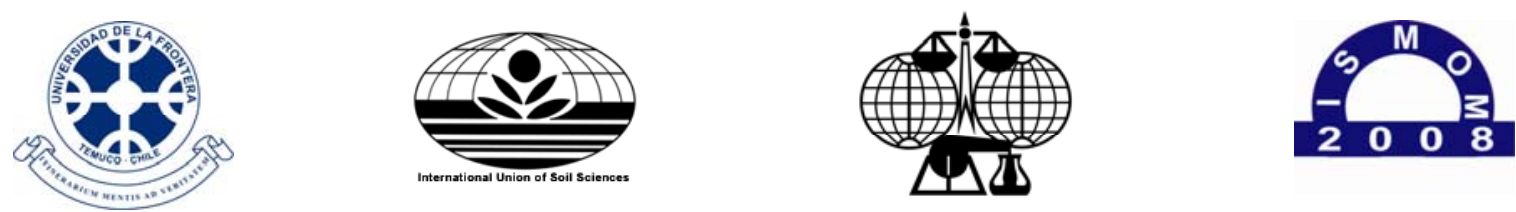

$5^{\text {th }}$ International Symposium ISMOM 2008 - November $24^{\text {th }}-28^{\text {th }}, 2008$ - Pucón, Chile

Keynote papers

1. The shift in the optimal $\mathrm{pH}$ of activity should give rise to a higher rate of catalytic activity for the adsorbed enzyme than for the enzyme in solution in the alkaline range of $\mathrm{pH}$. This has never been observed. When the absolute values of catalytic activity are reported, they invariably show that the values for the adsorbed enzyme are contained in the enveloppe of the values for the enzyme in solution (Aliev et al. 1976; Quiquampoix, 1987a; Quiquampoix, 1987b; Quiquampoix et al., 1989; Leprince and Quiquampoix, 1996). A misleading presentation of the results which is partly responsible for the popularity of this hypothesis in soil science and biotechnology is the normalization of enzyme activity values to the maximum value attained for each case, free and bound (Mc Laren and Estermann, 1957; Durand, 1964; Goldstein et al., 1964; Douzou and Petsko, 1984). This masks the occurence of the general decrease in catalytic activity.

2. The hypothesis implies that the conformation of the adsorbed enzyme is similar to the conformation of enzyme in solution and can act as a "molecular pH-meter". Ample evidence to the contrary has been presented above.

3. Finally the basis of this theory is far from being assured since, as some authors have pointed out (Rouxhet, 1990; Rouxhet and Mozes, 1990; Fletcher, 1991), the tendency of a proton to react with the active site of the enzyme is not given by the proton activity but by its molar free enthalpy, namely its electrochemical potential:

$$
\mu=\mu_{0}+\mathrm{RT} \ln \left[\mathrm{H}^{+}\right]+\mathrm{F} \psi
$$

And since the system is in a state of thermodynamical equilibrium, the molar free enthalpy of the proton is the same in the bulk of the solution and at the clay surface.

The second hypothesis is based on evidence of $\mathrm{pH}$ dependent modifications of protein conformation. An Aspergillus niger $\beta$-D-glucosidase exhibits decreasing relative activity, $\mathrm{R}$, defined as the ratio of activity in the adsorbed state and activity of an equal amount in solution, with decreasing $\mathrm{pH}$. The attractive electrostatic interactions between the positively charged protein and the negatively charged clay surface, which lead to the unfolding of the enzyme, play a major role. The fraction of the enzyme which is not adsorbed, F, increases with increasing $\mathrm{pH}$. Again electrostatic forces are the main determinant of this behaviour, but this time between a negatively charged enzyme and the negatively charged clay surface. The Aspergillus niger $\beta$-D-glucosidase is an example of enzyme for which electrostatic interactions probably completely regulate the interactions with clay surfaces.

\section{Irreversibility of the structural alteration of adsorbed enzymes}

Further evidence for the theory of the pH-dependent modification of conformation of adsorbed enzymes which relies purely on catalytic activity measurements, and which is independent of the information obtained by the physical methods presented above, can be obtained. An example is the effect of the adsorption of an enzyme at a given $\mathrm{pH}$ followed by the measurement of its catalytic activity on a wider range of $\mathrm{pH}$. It can be observed that, the lower the $\mathrm{pH}$ of adsorption on montmorillonite, the lower is the measured catalytic activity of the enzyme at a given $\mathrm{pH}$. This 

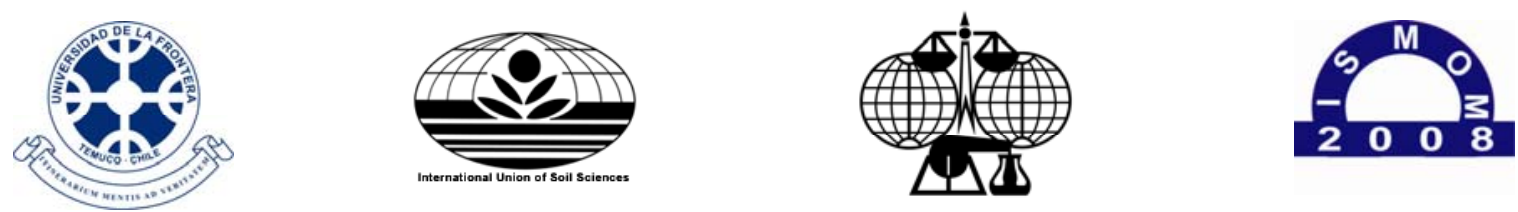

$5^{\text {th }}$ International Symposium ISMOM 2008 - November $24^{\text {th }}-28^{\text {th }}, 2008$ - Pucón, Chile

Keynote papers

result cannot be explained by the surface $\mathrm{pH}$ effect since, according to this theory; no lasting effect of the $\mathrm{pH}$ at the moment of adsorption should be detected when the catalytic activity is measured at another $\mathrm{pH}$. The change in activity cannot therefore be due to a modification of local $\mathrm{pH}$.

Conversely, a modification of conformation is compatible with this observation, since the higher extent of unfolding at the lower $\mathrm{pH}$ values creates a higher number of contact points between the protein and the clay surface. The consequence is that, in order to return to its original conformation, the adsorbed enzyme would require an energy of activation corresponding to the energy of adsorption of all the additional amino acids brought into contact with the solid surface. It is likely that this activation energy is higher than the thermal energy available to the system.

\section{Effect of the hydrophobicity/hydrophilicity of the surfaces on enzyme activity}

Adsorption of proteins on artificial organic surfaces is known to involve hydrophobic interactions (Norde, 1986). The occurence of this type of interaction can also be shown on some mineral surfaces. The destabilizing effect of different surfaces on a sweet almond $\beta$-D-glucosidase conformation can be estimated by the effect on its relative activity $\mathrm{R}$. It can be observed that the minimal destabilization of the enzyme structure is obtained with adsorption on goethite in a citrate buffer (Quiquampoix, 1987a). This surface is hydrophilic and with a low electric charge due to the complexation of the citric acid with the hydroxyls of the oxide surface. The occurence of hydrophobic interactions is shown by the larger destabilizing effect of the uncharged hydrophobic talc surface (Quiquampoix et al., 1989). Compared to the goethite and talc surfaces, the negatively charged surface of montmorillonite confirms the strength of electrostatic interactions since the most important denaturation of the enzyme structure is observed on this surface at $\mathrm{pH}$ below 4 when the enzyme bears a net positive charge.

An interesting additional observation is that the effect of an increase of the ionic strength does not suppress the unfolding of the enzyme at $\mathrm{pH}$ below 4, as could be expected for an electrostatic interaction. The absence of an effect of the ionic strength on the interaction between a cationic polymer and a negatively charged surface has been observed with the adsorption of ammonium substituted galactomannans (Gu and Doner, 1992) on illite surfaces and has been attributed to a surface charge neutralization of the negative charge of the illite which is independent of the ionic strength. In contrast the anionic carboxyl substitued galactomannans (Gu and Doner, 1992) show an adsorption behavior dependent on the ionic strength, like the adsorption of the sweet almond D-glucosidase above its i.e.p. (Quiquampoix, 1987a). Thus attractive and repulsive electrostatic interactions between polymers and clay surfaces seem to show different sensitivities to the ionic strength.

Finally the relative activity of the enzyme on montmorillonite at high ionic strength and high $\mathrm{pH}$ is similar to that observed on the hydrophobic talc. The decrease in the repulsive electrostatic interactions and the fact that the hydrophilic nature of the montmorillonite surface is due to the hydration properties of the exchangeable cations, and not to the siloxane surface which is hydrophobic (Chassin et al., 1986; Skipper et al., 1989; Bleam, 1990; Jaynes and Boyd, 1991), are two factors which may explain this convergence. Additional evidence for the occurence of hydrophobic interactions between proteins and montmorillonite surfaces is the increase in adsorption when proteins are methylated (Staunton and Quiquampoix, 1994). 

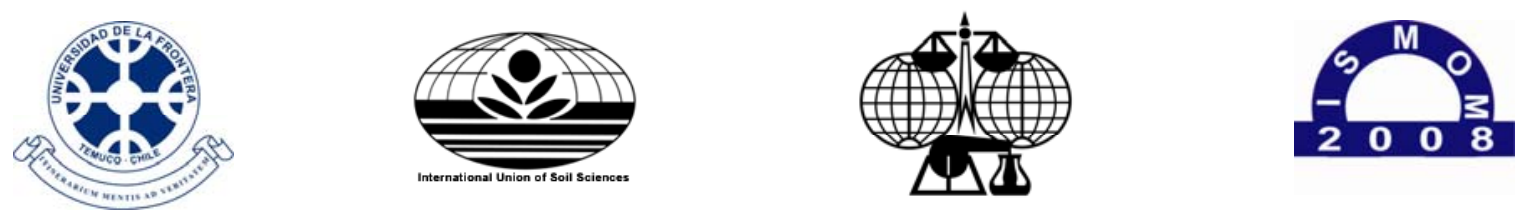

$5^{\text {th }}$ International Symposium ISMOM 2008 - November $24^{\text {th }}-28^{\text {th }}, 2008$ - Pucón, Chile

Keynote papers

\section{Interfacial competition of adsorption of enzymes on natural clay-humic complexes}

The real situation in soil is not represented by the presence of "clean" uncoated mineral surfaces as adsorbent surfaces for enzymes, but by the presence of organo-mineral complexes, and above all clay-humic complexes (Theng, 1979; Fusi et al., 1989; Rao et al, 1996). The heterogeneity of the soil organic matter is such that the study of better defined artificial clay-organic complexes is helpful to understand the mechanisms implied.

The effect of different clay-organic complexes on the relative activity of a sweet almond $\beta$-D glucosidase can illustrate the interfacial competition for the mineral surfaces. The lysozymemontmorillonite complex involves a protein with a high i.e.p. (11.7). For this reason it is strongly held on the clay surface and renders the surface electropositive. As a result there is no evidence of the unfolding observed with the uncoated montmorillonite surface, which was caused by attractive electrostatic interactions. The enzyme appears to unfold on the polyethylene glycol-montmorillonite complex at low $\mathrm{pH}$, as on the uncoated clay surface. This occurs because the adsorption of the positively charged enzyme on the electronegative clay surface is energetically more favourable than that of polyethylene glycol which is thus displaced. As the $\mathrm{pH}$ increases the enzyme loses its positive charge and hence its ability to displace the polyethylene glycol. The higher relative activity in this $\mathrm{pH}$ range may be explained by a reduction in the destabilizing hydrophobic interactions because a hydrated polymer layer is intercalated between the enzyme and the surface (Quiquampoix, 1987b).

A natural clay-humic fraction (mineral fraction composed of smectite, interstratified minerals, illite and kaolinite; organic fraction composed of 21\% fulvic acid, 29\% humic acid and 50\% humin) shows an intermediate destabilizing effect on the enzyme. It has been proposed that there is a lower energy of interaction for some of the natural humic substances with the clay surfaces, which are thus more easily exchanged than polyethylene glycol (Quiquampoix, 1987b). Thus the interaction of an enzyme with a mixture of several natural clay minerals, coated with poorly defined natural organic matter, can be adequately explained by taking in account of electrostatic interactions, hydrophobic interactions and interfacial competition of adsorption observed on a very simple model such as a polyethylene glycol-montmorillonite complex.

\section{Conclusions}

The adsorption of enzymes on mineral surfaces is a complex phenomenon which involves both enthalpic and entropic effects. An important and difficult question is the determination of possible changes of conformation of the adsorbed enzyme. NMR and FTIR spectroscopies are useful tools to answer this question since they respectively give information on the interfacial area of the surface of contact of protein-clay and on the secondary structure of adsorbed proteins. It has been shown that both $\mathrm{pH}$-dependent modification of conformation and $\mathrm{pH}$-dependent orientation of the catalytic site of the enzyme can explain the alkaline $\mathrm{pH}$ shift of the enzyme activity on electronegative soil mineral surfaces. Soft proteins, such as BSA, are more prone to the first mechanism, whereas hard proteins, such as $\alpha$-chymotrypsin are more prone to the second. In addition to electrostatic forces, hydrophobic interactions are also implied in the interaction of proteins with clays. An important 

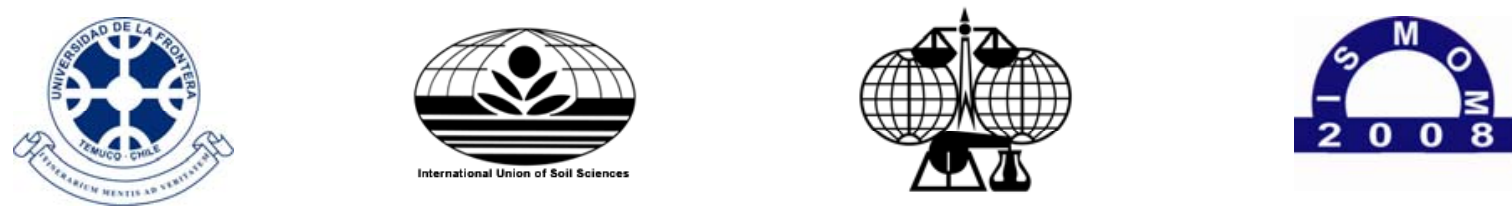

$5^{\text {th }}$ International Symposium ISMOM 2008 - November $24^{\text {th }}-28^{\text {th }}, 2008$ - Pucón, Chile

Keynote papers

aspect is the interplay between different driving forces in adsorption. For example, the hydrophobic interactions with clays can result from an electrostatic exchange of the hydrophilic counterions on the clay surface leaving a hydrophobic siloxane surface. The rearrangement of the protein structure on the clay surface subsequently can be facilitated when hydrophobic amino acids come in contact with the hydrophobic siloxane layer and remain shielded from the water molecules of the solution. If this rearrangement is accompanied by a decrease of ordered secondary structures, it would result in an additional increase in conformational entropy, lowering the Gibbs energy of the system. The combination of all these different subprocesses is responsible for the irreversible aspects of the modifications of conformation of enzymes on clay surfaces.

The concepts which have been introduced in this text are more developed in other publications (Quiquampoix, 2000; Quiquampoix et al., 2002; Quiquampoix and Burns, 2007; Quiquampoix, 2008).

Keywords: Proteins; enzymes; clay-humic complexes.

\section{References}

J.T. Albert and R.D. Harter. (1973). Soil Sci. 115: 130-136.

R.A. Aliev, V.S. Gusev and D.G. Zvyagintsev. (1976). Vestn. Mosk. Univ. Biol. Pochvoved. 31: 67-70.

D.E. Armstrong and G. Chesters . (1964). Soil Sci. 98: 39-52.

W.F. Bleam. (1990). Clays Clay Min. 38: 527-536.

M.H. Baron, M. Revault, S. Servagent-Noinville S. et al. (1999). J. Colloid Interface Sci. 214: 319-332.

P. Brown and D.C. Gajdusek. (1991). The Lancet 337: 269-270.

P. Chassin, C. Jouany and H. Quiquampoix. (1986). Clay Miner. 21: 899-907.

P. Douzou and G.A. Petsko. (1984). Adv. Protein Chem. 36: 245- 361.

G. Durand . (1964). Adv. Microbial Physiol. 32: 53-85.

P. Fusi, G.G. Ristori, L. Calamai and G. Stotzky. (1989). Soil Biol. Biochem. 21: 911-920.

L. Goldstein, Y. Levin and E. Katchalski. (1964). Biochemistry 3: 1913-1919.

B. Gu and H.E. Doner. (1992). Clays Clay Min. 40: 151-156.

R.D. Harter and G. Stotzky. (1973). Soil Sci. Soc. Am. Proc. 37: 116-123.

C.A. Haynes and W. Norde. (1994). Colloids Surfaces B: Biointerfaces 2: 517-566.

T.A. Horbett and J.L. Brash. (1987). Proteins at interfaces : current issues and future prospects. In J.L. Brash and T.A. Horbett, Proteins at Interfaces. Physicochemical and Biochemical Studies. Washington DC : ACS Symposium Series 343, pp 1-33.

W.F. Jaynes and S.A. Boyd. (1991). Clays Clay Min. 39: 428-436.

A. Kondo, S. Oku and K. Higashitani . (1991). J. Colloid Interface Sci. 143: 214-221.

N. Larsson and B. Siffert. (1983). J. Colloid Interface Sci. 93: 424-431.

F. Leprince and H. Quiquampoix H. (1996). Eur. J. Soil Sci. 47: 511-522.

M.J. Loll and J.-M. Bollag. (1983). Adv. Agron. 36: 351-382.

A.D. Mc Laren and E.F. Estermann. (1957). Influence of $\mathrm{pH}$ on the activity of chymotrypsin at a solid-liquid interface. Arch. Biochem. Biophys. 68: 157-160.

A.D. Mc Laren, G.H. Peterson and I. Barshad. (1958). Soil Sci. Soc. Am. Proc. 22: 239-244.

S. Noinville, M. Revault, H. Quiquampoix and M.H. Baron. (2004). J. Colloid Interface Sci. 273: 414-425.

W. Norde. (1986). Adv. Colloid Interface Sci. 25: 267-340.

W. Norde and J. Lyklema. (1991). J Biomater Sci Polymer Edn. 2: 183-202.

S. Pagel-Wieder, F. Gessier, J. Niemeyer and D. Schröder. (2004). J. Plant Nutr. Soil Sci. 167: 184-188.

H. Quiquampoix. (1987a). Biochimie 69: 753-763.

H. Quiquampoix. (1987b). Biochimie 69: 765-771. 

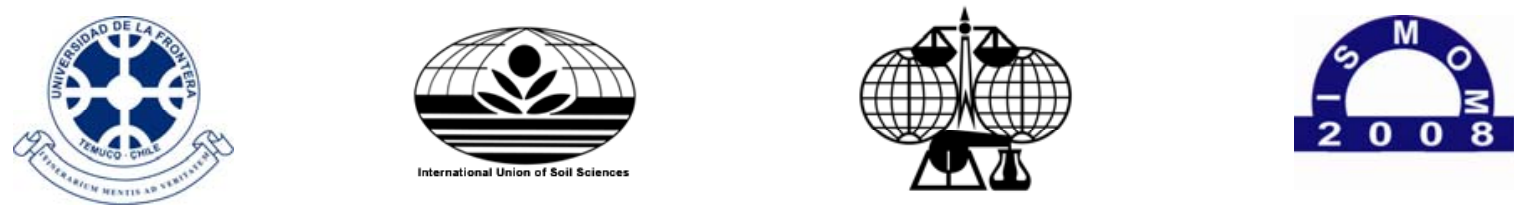

$5^{\text {th }}$ International Symposium ISMOM 2008 - November $24^{\text {th }}-28^{\text {th }}, 2008$ - Pucón, Chile

\section{Keynote papers}

H. Quiquampoix. (2000). Mechanisms of protein adsorption on surfaces and consequences for extracellular enzyme activity in soil. In: Bollag J.M. and Stotzky G., Soil Biochemistry, Vol 10. Marcel Dekker, Inc. New York., pp 171-206.

H. Quiquampoix. (2008). Enzymes and proteins, interactions with soil constituent surfaces. In: W. Chesworth, Encyclopedia of Soil Science, Springer, Dordrecht, Berlin, Heidelberg, New York, pp. 210-216.

H. Quiquampoix and R.G. Burns. (2007). Elements 3: 401-406.

H. Quiquampoix, P. Chassin and R.G. Ratcliffe. (1989). Prog. Colloid Polym. Sci. 79: 59-63.

H. Quiquampoix and D. Mousain. (2005). Enzymatic hydrolysis of organic phosphorus. In: Turner B.L., Frossard E. and Baldwin D., Organic Phosphorus in the Environment. CAB International. Wallingford, pp. 89-112.

H. Quiquampoix and R.G. Ratcliffe. (1992). J. Colloid Interface Sci. 148: 343-352.

H. Quiquampoix, S. Servagent-Noinville and M.H. Baron. (2002). Enzyme adsorption on soil mineral surfaces and consequences for the catalytic activity. In: Burns R.G and Dick R.P. Enzymes in the Environment: Activity, Ecology and Applications. Marcel Dekker, Inc. New York, pp 285-306.

H. Quiquampoix, S. Staunton, M.-H. Baron and R.G. Ratcliffe. (1993). Colloids Surf. A 75: 85-93.

M.A. Rao, L. Gianfreda, F. Palmiero and A. Violante. (1996). Soil Sci. 161: 751-760.

M. Revault, H. Quiquampoix, M.H. Baron and S. Noinville S. (2005). Fate of prions in soil : Trapped conformation of full-length ovine prion protein induced by adsorption on clays. Biochim. Biophys. Acta. In press (online on ScienceDirect).

P.G. Rouxhet. (1990). Immobilization of biocatalysts and interfacial chemistry. In: *Okada H.; Tanaka A. and Blanch H.W., Annals of the New York Academy of Sciences, Volume 613, Enzyme Engineering 10. New York: The New York Academy of Sciences, pp 265278.

P.G. Rouxhet and N. Mozes. (1990). The micro-environment of immobilized cells: critical assessment of the influence of surfaces and local concentrations. In: de Bont J.A.M.; Visser J., Mattiasson B. and Tramper J., Physiology of Immobilized Cells. Amsterdam: Elsevier Science Publishers, pp 343-354.

S. Servagent-Noinville, M. Revault, H. Quiquampoix and M.H. Baron. (2000). J. Colloid Interface Sci. 221: 273-283.

N.T. Skipper, K. Refson and J.D.C. McConnell. (1989). Clay Miner. 24: 411-425.

S. Staunton and H. Quiquampoix. (1994). J. Colloid Interface Sci. 166: 89-94.

H. Tapp and G. Stotzky G. (1998). Soil Boil. Biochem. 30: 471-476.

I. Tarasevich Yu., V.A. Smirnova, L.I. Manakhova L.I., Ropot V.M. and Sivalov E.G. (1975). Kolloidnyi Zhurnal 37: $912-917$.

B.K.G. Theng. (1979). Formation and Properties of Clay-Polymer Complexes, Amsterdam, Elsevier, p362. 